\title{
А.О. Волосовець
}

\section{АНАЛІЗ ВАРІАБЕЛЬНОСТІ АРТЕРІАЛЬНОГО ТИСКУ В ПАЦІЕНТІВ З ГОСТРИМ МОЗКОВИМ ІНСУЛЬТОМ ЗАЛЕЖНО ВІД ЧАСУ ВИНИКНЕННЯ}

Національна медична академія післядипломної освіти ім. П.Л. Шупика

кафедра медицини невідкладних станів

(зав. - д. мед. н., проф., академік АН Вищої Освіти Украӥни І.С. Зозуля)

вул. Дорогожииька, 9, Київ, 04112, Україна

Shupyk National medical academy of postgraduate education

Department of Emergency Medicine

Dorohozhytska str., 9, Kyiv, 04112, Ukraine

e-mail: office@nmapo.edu.ua

Ключові слова: ішемічний інсульт, артеріальний тиск, патерни коливання, моніторинг

Key words: ischemic stroke, arterial pressure, patchy vibration, monitoring

Реферат. Анализ вариабельности артериального давления у пациентов с острым мозговым инсультом в зависимости от времени возникновения. Волосовець А.А. Артериальная гипертензия способна оказывать выраженное негативное влияние на состояние церебральной сосудистой системь и приводить к значительной микротравматизации стенок сосудов и срыва сосудистой ауторегуляичии. Данный предиктор имеет наибольшее влияние на возникновение ишемического инсульта атеротромботического и лакунарного подтипов, однако АГ встречается почти у всех пациентов с острой ишемией мозга. Интересным и вовсе не представленным в современной научной литературе является вопрос о взаимосвязи колебания АД с периодом суток возникновения очага ишемии, что и обусловило иель нашей работы. Целью нашего исследования было определить взаимосвязь деформаџии профиля колебания артериального давления пациентов в острый период ишемического инсульта в зависимости от времени возникновения иереброваскулярной катастрофы. Нами было обследовано 300 больных, перенесших острый ишемический инсульт (мужчин - 196, женщин - 104) в возрасте от 42 до 84 лет (средний возраст - 65,2 8,7 года). Всех пациентов разделили на 3 группь по времени суток, когда возник ишемический инсульт: 1 группа $(n=146)$, пациенты которой пострадали от ичеребральной ишемии в дневной период (8.00-14.59), 2 группа $(n=107)$, среди пациентов которой инсульт наблюдался в вечернее время (15.00-21.59), 3 группа (n=47), где у паџиентов ишемический инсульт возникал в ночное время (22.00-7.59). Для 1-й группь пациентов, у которых ишемический инсульт произошел в дневной период и как правило на фоне повышения АД, характерно выраженное повышение АД в периоды 12.00 и 15.00 и тенденция к компенсаторному парасимпатическому влиянию в виде снижения АД в ночное время (over-dipper). В то же время во 2-й группе пациентов с инсультами в вечернее время наблюдались повышение АД в периоды 18.00 и 21.00 и расстройства парасимпатической активности с преобладанием недостаточного снижения АД в вечернее время и во время сна (поп-dipper). Для пациентов с ночным инсультом (третья группа) характерным было наличие двух пиков повышения АД в периоды 9.00 и 21.00 и значительное повышение АД ночью (nightpeaker), что обычно и приводило к возникновению цереброваскулярной катастрофы. Резкие изменения биоритма жизненного цикла человека в значительной степени влияют на нарушение регуляиии вегето-сосудистой системы и приводят к срыву регулящии сосудистого тонуса с возникновением феноменов «вегетативной бури» и резкого повышения АД по типу «night peacker». Подобный эффект вызывает и хроническая алкогольная интоксикация, вероятно из-за токсического поражения гипоталамо-гипофизарного комплекса вследствие высокой проницаемости гематоэнцефалического барьера в этой области мозга из-за чрезмерно активной гормонально-регуляторной диффузии.

Abstract. Analysis of arterial pressure variability in patients with acute cerebral stroke depending on the time of occurrence. Volosovets A.O. Arterial hypertension can cause a pronounced negative influence on the state of the cerebral vascular system and lead to significant microtraumatization of the walls of the vessels and disruption of vascular autoregulation. This predictor has the greatest influence on the onset of ischemic stroke of atherothrombotic and lacunar subtypes, however, hypertension occurs almost in all patients with acute cerebral ischemia. Interesting and not at all presented in modern scientific literature is the question of the relationship of oscillation of blood pressure with the period of the onset of the focus of ischemia, which predetermined the purpose of our work. The purpose of our study was to determine the relationship between deformation of the profile of fluctuations in blood pressure of patients in the acute period of ischemic stroke, depending on the time of the occurrence of cerebrovascular accident. We examined 300 patients who suffered acute ischemic stroke (men - 196, women -104) aged 42 to 84 years (average age $65.2 \pm 8.7$ years). All patients were divided into 3 groups according to the period of the day when an ischemic stroke 
occurred: 1 group ( $n=146$ ), patients suffering from cerebral ischemia during the day (8.00-14.59); In group 2 ( $n=107$ ), patients stroke was observed in the evening (15.00-21.59); Group $3(n=47)$, patients had an ischemic stroke at night (22.00-7.59). For the 1st group of patients who have had ischemic stroke during the day and as a rule with an increase in blood pressure, a marked increase in blood pressure was at 12.00 and 15.00 and a tendency towards compensatory parasympathetic effect in the form of blood pressure decrease at night (over-dipper) was typical. At the same time, in the 2nd group of patients with stroke in the evening, elevated blood pressure at 18.00 and 21.00 and parasympathetic activity disorders with prevalence of insufficient reduction of blood pressure in the evening and during sleep (nondipper) was observed. For patients with a nocturnal stroke (3rd group), there were two peaks of elevated blood pressure at 9.00 and 21.00 and a significant increase in night-peaking at night, which usually resulted in a cerebrovascular catastrophe. Sharp changes in human biorhythm significantly affect the violation of the regulation of the vegetative-vascular system and lead to a breakdown in the regulation of vascular tone with the emergence of phenomena of "vegetative storm" and sharp increase in blood pressure by the type of "night peacker". This effect is also caused by chronic alcohol intoxication, presumably due to the toxic damage of the hypothalamic-pituitary complex due to the high permeability of the blood-brain barrier in this area of the brain due to over-active hormonal-regulatory diffusion.

Артеріальна гіпертензія (АГ) є найпоширенішим модифікованим фактором ризику інсульту. Причому при зниженні артеріального тиску (АТ) спостерігається і зниження частоти рецидивів інсульту [8]. Проте особливості коливання АТ протягом гострого періоду ішемічного інсульту ще й досі залишається маловивченим питанням [11].

Незважаючи на те, що в багатьох клінічних дослідженнях було проведено корекцію та керування коливаннями артеріального тиску серед пацієнтів $з$ гострим ішемічним інсультом, на сьогодні немає остаточних даних, які свідчать про те, що лікування при подібних гострих станах може істотно змінити клінічні наслідки для таких пацієнтів [2, 3, 7, 13].

Відповідно до Рекомендацій Американської кардіологічної асоціації (АНА) за 2013 рік для раннього лікування хворих на гострий ішемічний інсульт, ідеальний діапазон артеріального тиску при гострому ішемічному інсуліні не визначався, але, ймовірно, залежить від факторів, специфічних для хворого [5].

Рівень артеріального тиску, як правило, є максимальним при госпіталізації пацієнта, але спонтанно зменшується протягом природного патогенетичного перебігу інсультного процесу $[6,10]$. Незважаючи на те, що подібна тенденція спостерігається і в інших групах пацієнтів без інсульту, показники АТ все одно вище в пацієнтів 3 інсультом [9]. Одне дослідження показало, що систолічний артеріальний тиск при надходженні пацієнта був значно вищим у тих пацієнтів, які страждають на ішемічний лакунарний і тромбоемболічний інфаркти мозку, ніж в інших пацієнтів (середні, 13,2\% та 8,6\% відповідно) 3 аналогічним підвищенням діастолічного артеріального тиску, але відмінності більше не були значними при повторному контрольному оцінюванні на 7 день [12]. Спон- танні зниження артеріального тиску тривають протягом кількох днів після виникнення цереброваскулярної події [4].

Представлені дані дозволяють уявити, наскільки неоднозначним і в той же час вагомим фактором $є$ артеріальна гіпертензія. Артеріальна гіпертензія здатна спричинювати виражений негативний вплив на стан церебральної судинної системи i призводити до значної мікротравматизації стінок судин та зриву судинної ауторегуляції. Цей предиктор має найбільший вплив на виникнення ішемічного інсульту атеротромботичного та лакунарного підтипів, проте АГ зустрічається майже у всіх пацієнтів 3 гострою ішемією мозку [1]. Цікавим і зовсім не представленим у сучасній науковій літературі $€$ питання про взаємозв'язок коливання АТ 3 періодом доби виникнення вогнища ішемії, що й зумовило мету нашої роботи.

Метою нашого дослідження було визначити взаємозв язок деформації профілю коливання артеріального тиску пацієнтів у гострий період ішемічного інсульту залежно від часу виникнення цереброваскулярної катастрофи.

\section{МАТЕРІАЛИ ТА МЕТОДИ ДОСЛІДЖЕНЬ}

Нами було обстежено 300 хворих, які перенесли гострий ішемічний інсульт (чоловіків 196, жінок - 104) віком від 42 до 84 років (середній вік - 65,2 $\pm 8,7$ року). Критеріями включення в це дослідження були: вік пацієнтів від 40 до 85 років; верифікований на МРТ ішемічний характер вогнища інсульту; згода пацієнта або його законного представника.

Всіх пацієнтів розподілили на 3 групи згідно 3 періодом доби, коли виник ішемічний інсульт: 1 група (n=146), пацієнти якої постраждали від церебральної ішемії в денний період (8.00-14.59); 2 група ( $\mathrm{n}=107)$, серед пацієнтів якої інсульт спостерігався у вечірній час (15.00-21.59); 3 група ( $\mathrm{n}=47)$, де в пацієнтів ішемічний інсульт 
виникав у нічний час (22.00-7.59). Всім пацієнтам було проведене клініко-неврологічне обстеження хворих 3 використанням структурованих шкал, комп'ютерна томографія, магнітно-резонансна томографія та дифузійно-зважена МРТ головного мозку, добовий моніторинг АТ, клініко-лабораторні та статистичні методи.

\section{РЕЗУЛЬТАТИ ТА ЇХ ОБГОВОРЕННЯ}

Враховуючи те, що артеріальна гіпертензія була виявлена в тій чи іншій мірі у всіх пацієнтів, у всіх групах хворих проводився моніторинг артеріального тиску протягом доби, що дозволило виявити цікаву тенденцію в патернах коливань цього показника в різні періоди часу залежно від того, коли саме виникла початкова інсультна симптоматика.

Так, для пацієнтів, які належали до групи «денного» інсульту, характерною була така характеристика коливань АТ (рис. 1).

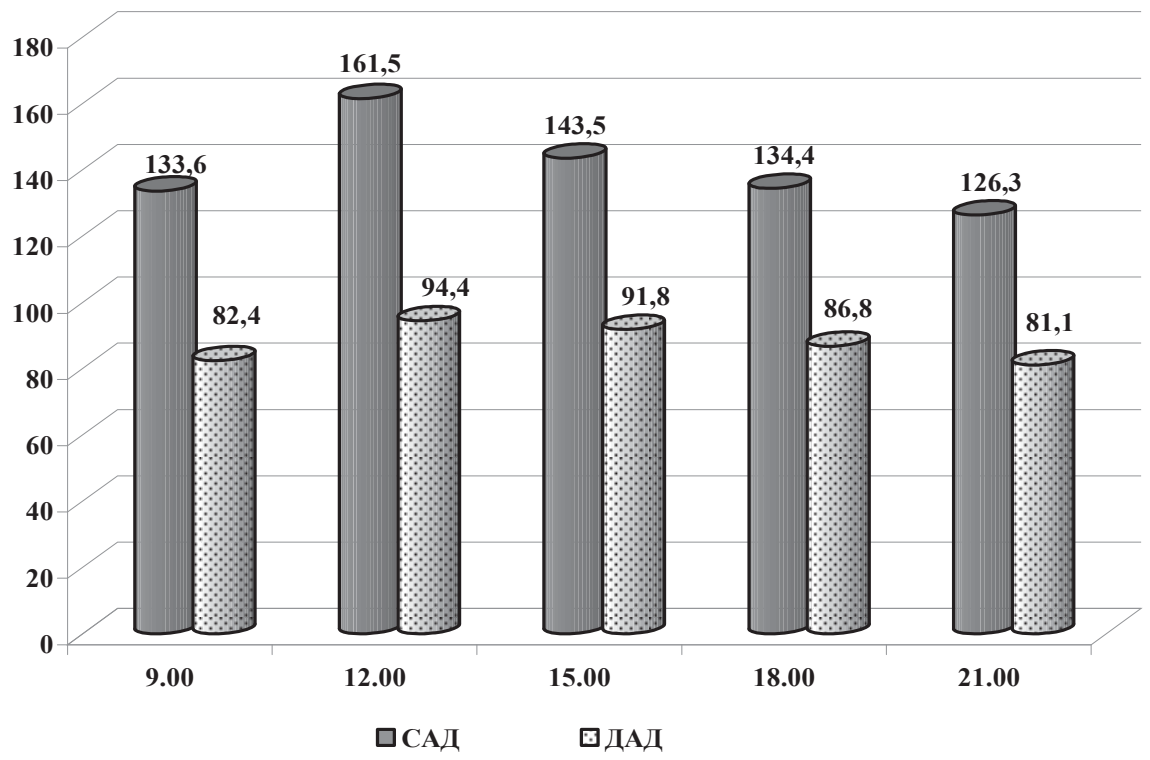

Рис. 1. Характеристика коливань артеріального тиску серед паціснтів з гострим ішемічним інсультом, що виник у денний період доби

На основі отриманих даних можна побачити, що для таких пацієнтів спостерігалася тенденція до незначного підвищення АТ у період 9.00, що може бути пов'язано 3 надмірною активацією симпато-адреналової системи у зв'язку із пробудженням, проте в період 12.00 середні показники як систолічного, так і діастолічного тиску були виражено підвищені, в середньому на $15,8 \%$ від верхньої межі фізіологічної норми, демонструючи підвищення на 2,8\% о 15.00 та поступово повертаючись у фізіологічні межі о 18.00. Подібна картина показує, що активність симпато-адреналової системи в денний період доби значно превалює в таких пацієнтів, що імовірно пов'язано зі зривом механізмів ауторегуляції судинного тонусу внаслідок як довготривалого догоспітального надмірного психогенного навантаження (фактор надмірної стресогенності оточення), так і паління в денний період (фактор шкідливих звичок) 3 хронічною гіпоксією та негативним впливом на тонус судин.
Під час оцінки нічного коливання АТ нами було виявлено, що для 1-ї групи характерним було превалювання в 78,1\% (n=114) підтипу over-dipper (зниження АТ вночі > 20\%), у 17,1\% $(\mathrm{n}=25)$ спостерігався підтип dipper (зниження АТ вночі на $10-20 \%)$ і в 4\% (n=6) - підтип non-dipper (зниження АТ вночі $<10 \%$ ) (рис. 2).

Отримані дані дозволяють зробити висновок про те, що для пацієнтів 1-ї групи, в яких інсульт стався в денний час і як правило на тлі підвищення АТ, характерним $є$ тенденція до компенсаторного парасимпатичного впливу у вигляді зниження АТ у нічний час (over-dipper). Подібна картина чітко показує своєрідний баланс надмірних показників АТ як у денний, так і в нічний періоди доби. Це свідчить про те, що нічне зниження тиску не мало безпосереднього патологічного підгрунтя й було своєрідною відновною компенсацією за надмірне навантаження на стінки судин вдень через хронічний стрес, гіпоксію та інтоксикацію головного мозку 
продуктами паління. Цікавим $є$ той факт, що зазвичай ці соціальні фактори є взаємопов’язаними, оскільки виснаження нервової системи на тлі стресу часто призводить до психо- фізіологічної залежності від паління тютюну, як зовнішнього донатора нікотину та елемента психологічної релаксації.

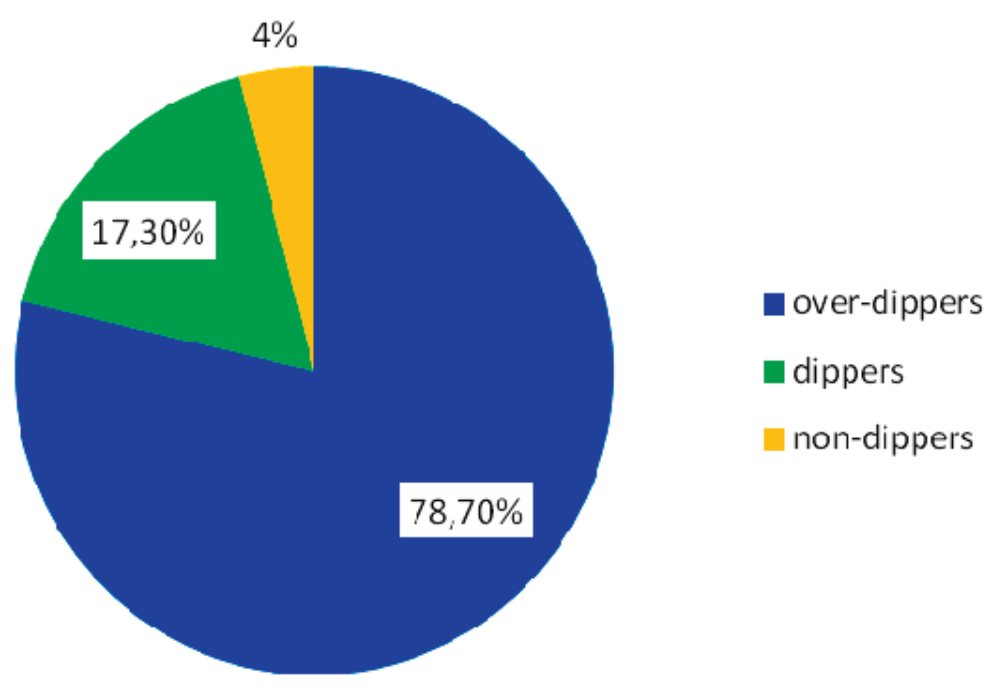

Рис. 2. Варіабельність нічного коливання артеріального тиску серед паціснтів з інсультом, що виник у денний період (8.00-14.59)

Патерн змін АТ серед пацієнтів 2-ї групи (ішемічний інсульт у вечірній час) мав дещо інше відображення (рис. 3).

Денна динаміка середніх показників САД та ДАД для пацієнтів 2-ї групи показала, що різке та виражене підвищення артеріального тиску, як у 1-й групі, для неї не характерно. Тут навпаки, спостерігалась тенденція до поступового підвищення як систолічного, так і діастолічного тиску, починаючи з періоду 15.00 з піком о 18.00 (хоча перевищення верхньої межі фізіологічної норми становило близько 5,01\%) та утримуванням підвищеного АТ о 21.00 (на 5,9\%) порівняно 3 ранковими показниками.

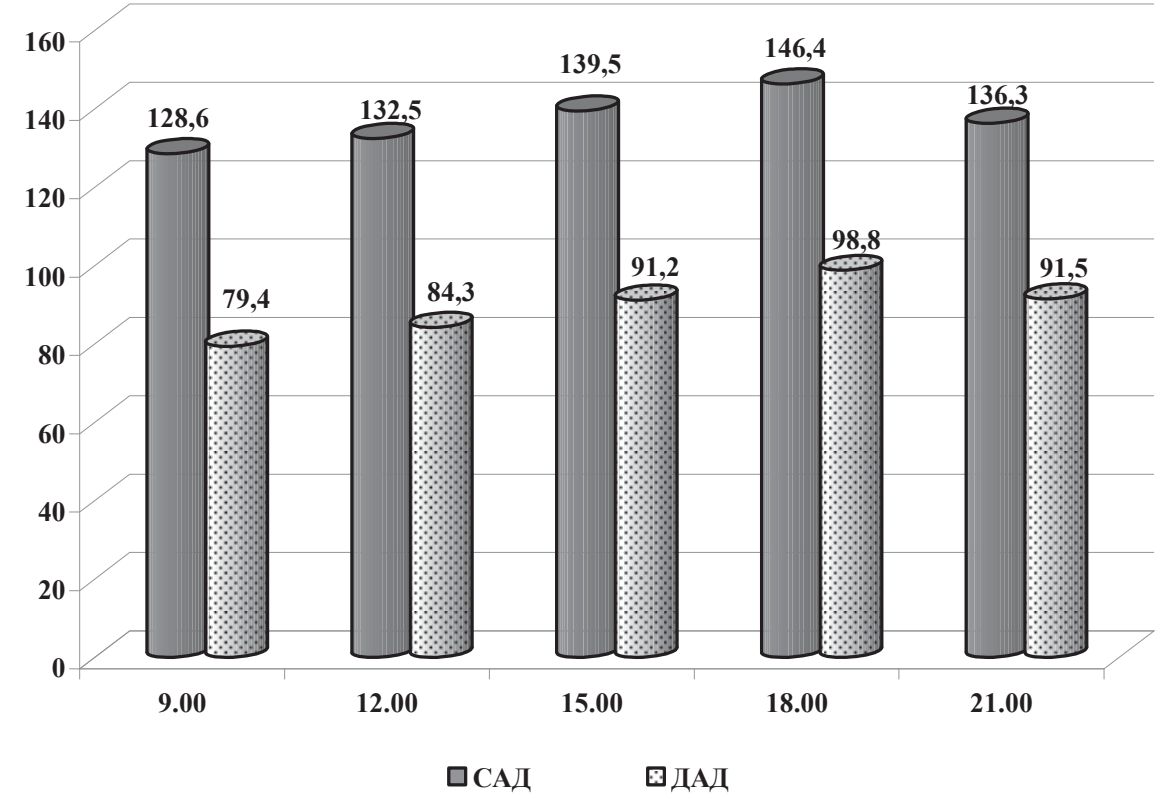

Рис. 3. Характеристика коливань артеріального тиску серед паціснтів з гострим ішемічним інсультом, що виник у вечірній період доби 
Тенденція до абнормального підвищення АТ зберігалась i під час нічного моніторингу. Зокрема, серед пацієнтів 2 групи в 76,1\% (n=35) переважав підтип non-dipper, підтип dipper спостерігався у $8,6 \%(n=4)$ і в $15,2 \%(n=7)$ виявляли підтип night-peaker (підвищення АТ вночі вище денного значення) (рис. 4).

Представлена схема динаміки артеріального тиску дозволяє зробити висновок про те, що для пацієнтів, у яких виник ішемічний інсульт у вечірній період, судинна реактивність демонструє відмінну від 1-ї групи тенденцію. Так, у разі підвищення АТ наростання тиску не було різким і спостерігалось переважно у вечірні години, що ми пов язували 3 нервовим виснаженням і втомою в кінці робочого дня в анамнезі пацієнтів та компенсацією хронічної ішемії мозку внаслідок високої частоти атерогенних стенозів судин екстра- та інтракраніального басейнів та частої механічної компресії судин (хребтових артерій) на тлі шийного остеохондрозу в результаті тривалої сидячої роботи без зміни неправильного положення тулуба, голови та шиї (фактори зниженої фізичної активності та довготривалої роботи 3 моніторами). Поступовий вплив описаних елементів призвів, на нашу думку, до формування компенсаторної моделі підвищення АТ для утримання адекватної оксигенації та живлення мозкової тканини шляхом підсилення перфузії через звужені стенозами та компресіями судини.

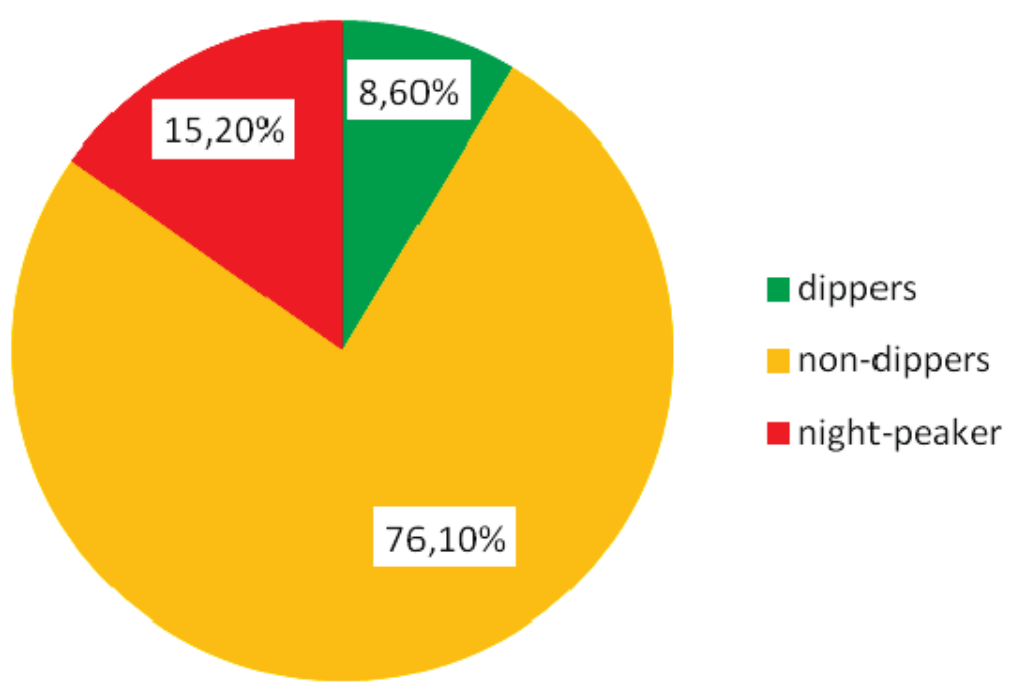

Рис. 4. Варіабельність добового коливання артеріального тиску серед пацієнтів з інсультом, що виник у вечірній період (15.00-21.59)

Аналіз даних, виявлених серед пацієнтів 3 ішемічним інсультом, що виник у нічний період, теж мав свої особливості (рис. 5).

Особливості динаміки артеріального тиску серед пацієнтів 3-ї групи полягали в тому, що, на відміну від хворих 1-ї та 2-ї груп, у таких пацієнтів спостерігалося два піки підвищення АТ - 9.00 та 21.00 відповідно. Зауважимо, що така модель варіабельності АТ, згідно 3 нашими спостереженнями, значною мірою асоційована зі зривом циркадної активності симпатичної системи i ii вимушеною стимуляцією в нічний період внаслідок надмірної нічної активності, порушень сну та активного нічного вживання алкоголю в анамнезі соціального ризику виникнення ішемічного інсульту в пацієнтів. Таке зміщення призводить до високого ризику підвищення АТ під час сну й зумовлює патологічне тло для виникнення цереброваскулярної катастрофи в нічний період доби.

Спостереження за нічним коливанням артеріального тиску серед таких пацієнтів лише підтверджує наші висновки, оскільки спектр підтипів 3-ї групи виглядав таким чином: $68,4 \%$ $(\mathrm{n}=13)$ - night-peaker, 26,3\% ( $\mathrm{n}=5)$ - non-dipper, $5,2 \%(\mathrm{n}=1)-$ підтип dipper (рис. 6). 


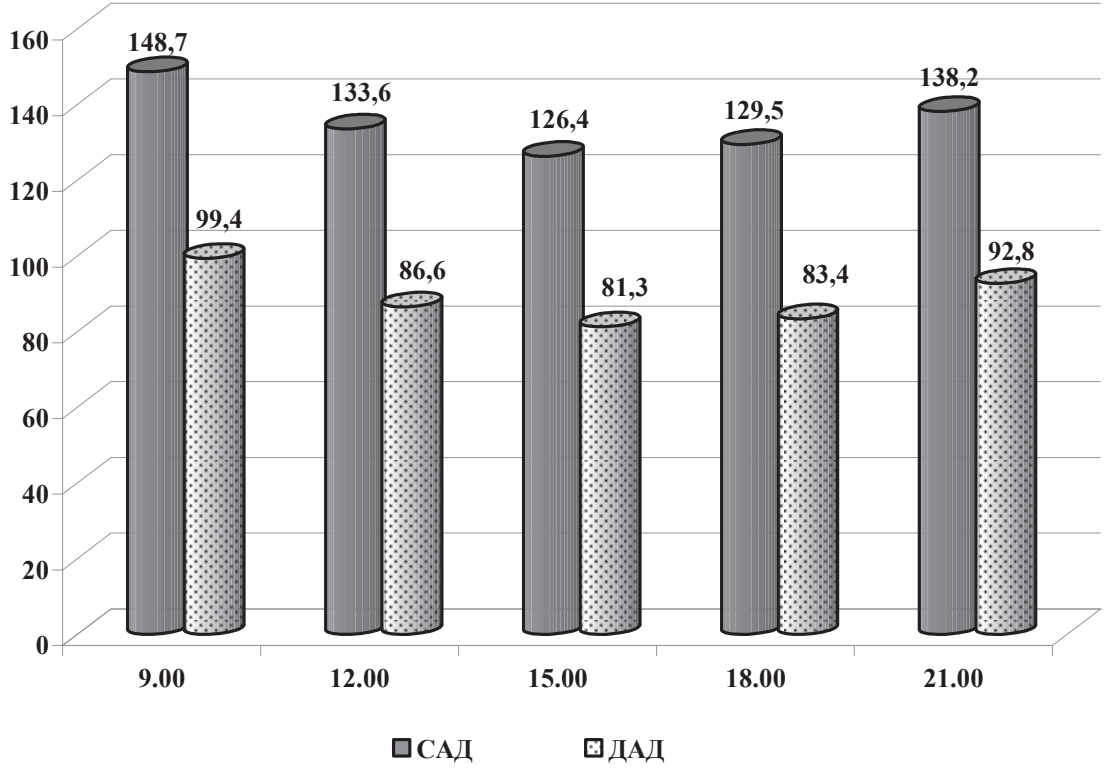

Рис. 5. Характеристика коливань артеріального тиску

серед паціснтів з гострим ішемічним інсультом, що виник у нічний період доби

Отримані дані дозволяють зробити висновок про те, що для пацієнтів 3-ї групи, в яких інсульт стався в нічний час, основним внутрішнім фактором ризику виникнення церебральної ішемії $€$ саме артеріальна гіпертензія. Проте варто зробити акцент на тому, що піки підвищення АТ серед таких хворих трапляються саме в нічний період, що протирічить стандартним добовим коливанням тиску, i 3 найбільшою імовірністю пов'язані зі способом життя пацієнтів, який вимагає від них надмірної активності саме в нічний період доби (охорона, нічне чергування, диспетчери, активне нічне життя тощо) і таким чином змушує організм підтримувати достатній рівень бадьорості та функціональності за рахунок хронічної неприродної стимуляції симпато-адреналової системи. Важливим $є$ той факт, що навіть після повернення людини до звичного денного режиму роботи та активності такий патологічний патерн коливання АТ продовжує утримуватись ще довгий час і як результат - може призвести до виникнення «нічного» інсульту.

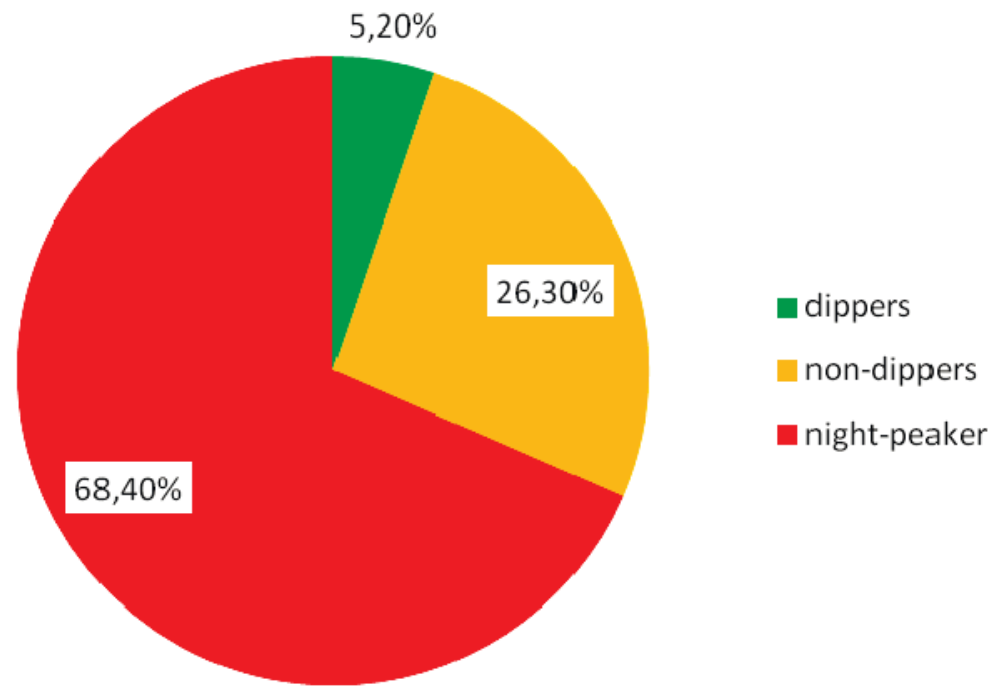

Рис. 6. Варіабельність добового коливання артеріального тиску серед паціснтів з інсультом, що виник у нічний період (22.00-7.59) 


\section{ВИСНОВКИ}

1. Таким чином, для 1-ї групи пацієнтів, у яких ішемічний інсульт стався в денний період $і$ як правило на тлі підвищення АТ, характерним $є$ виражене підвищення АТ у періоди 12.00 та $15.00 \mathrm{i}$ тенденція до компенсаторного парасимпатичного впливу у вигляді зниження АТ у нічний час (over-dipper). У той же час у 2-й групі пацієнтів 3 інсультами у вечірній час спостерігалися підвищення АТ у періоди 18.00 та 21.00 i розлади парасимпатичної активності 3 превалюванням недостатнього зниження АТ у вечірній час та під час сну (non-dipper). Для пацієнтів 3 нічним інсультом (3-я група) характерним була наявність двох піків підвищення АТ у періоди 9.00 та 21.00 і значне підвищення АТ вночі (night-peaker), що як правило і призводило до виникнення цереброваскулярної катастрофи.

2. Ці спостереження дозволяють зробити висновок про те, що різкі зміни біоритму життєвого циклу людини значною мірою впливають на порушення регуляції вегето-судинної системи та призводять до зриву регуляції судинного тонусу з виникненням феноменів «вегетативної бурі» та різкого підвищення АТ за типом «night peacker». Подібний ефект спричинює і хронічна алкогольна інтоксикація, імовірно через токсичне ураження гіпоталамогіпофізарного комплексу внаслідок високої проникності гематоенцефалічного бар'єру в цій ділянці мозку через надмірно активну гормонально-регуляторну дифузію.

\section{СПИСОК ЛІТЕРАТУРИ}

1. Зозуля І.С. Інсульти: тактика, стратегія ведення, профілактика, реабілітація та прогноз / I.C. Зозуля, Ю.І. Головченко, О.П. Оноприєнко. - Київ, 2010. - 320 с.

2. Blood-brain barrier is impaired in the hippocampus of young adult spontaneously hypertensive rats / M. Ueno, H. Sakamoto, H. Tomimoto [et al.] // Acta Neuropathol. - 2004. - Vol. 107. - P. 532-538.

3. Cortical hypoperfusion as a possible cause of 'subcortical aphasia' / T.S. Olsen, P. Bruhn, R.G. Oberg [et al.] // Brain. - 1986. - Vol. 109, N 3. - P. 393-410.

4. Effects of immediate blood pressure reduction on death and major disability in patients with acute ischemic stroke: the CATIS randomized clinical trial / J. He, Y. Zhang, T. Xu [et al.] // JAMA. - 2014. - Vol. 311. P. 479-489.

5. Guidelines for the early management of patients with acute ischemic stroke: a guideline for healthcare professionals from the American Heart Association. American Stroke Association / E.C. Jauch, J.L. Saver, H.P. Adams, A. Bruno [et al.] // Stroke. - 2013. - Vol. 44. - P. 870-947.

6. High blood pressure after acute ischemic stroke is associated with poor clinical outcomes: Fukuoka Stroke Registry / K. Ishitsuka, M. Kamouchi, J. Hata [et al.] // Hypertension. - 2014. - Vol. 63. - P. 54-60.

7. IST Collaborative Group. Blood pressure and clinical outcomes in the International Stroke Trial / J. Leonardi-Bee, P.M. Bath, S.J. Phillips [et al.] // Stroke. - 2002. - Vol. 33. - P. 1315-1320.
8. Lower target blood pressures are safe and effective for the prevention of recurrent stroke: the PROGRESS trial / H. Arima, J. Chalmers, M. Woodward [et al.] // J. Hypertens. - 2006. - Vol. 24 - P. 1201-1208.

9. Ntaios G. Blood pressure change and outcome in acute ischemic stroke: the impact of baseline values, previous hypertensive disease and previous antihypertensive treatment / G. Ntaios, D. Lambrou, P. Michel // J. Hypertens. - 2011. - Vol. 29. - P. 1583-1589.

10. Predicting the risk of symptomatic intracerebral hemorrhage in ischemic stroke treated with intravenous alteplase: safe Implementation of Treatments in Stroke (SITS) symptomatic intracerebral hemorrhage risk score / M. Mazya, J.A. Egido, G.A. Ford [et al.] // Stroke. 2012. - Vol. 43. - P. 1524-1531.

11. Prevalence of elevated blood pressure in 563,704 adult patients with stroke presenting to the ED in the United States / A.I. Qureshi, M.A. Ezzeddine, A. Nasar [et al.] // Am. J. Emerg. Med. - 2007. - Vol. 25. - P. 32-38.

12. Scandinavian Candesartan Acute Stroke Trial Study Group. Effects of blood pressure lowering in patients with acute ischemic stroke and carotid artery stenosis / M. Jusufovic, E.C. Sandset, P.M. Bath [et al.] // Int. J. Stroke. - 2015. - Vol. 10. - P. 354-359.

13. Vascular permeability precedes spontaneous intracerebral hemorrhage in stroke-prone spontaneously hypertensive rats / J.M. Lee, G. Zhai, Q. Liu [et al.] // Stroke. - 2007. - Vol. 38. - P. 3289-3291.

\section{REFERENCES}

1. Zozulya IS, Golovchenko YuI, Onoprienko O P. [Stroke: tactics, strategy of management, prevention, rehabilitation and prognosis]. 2010;320.

2. Ueno M, Sakamoto H, Tomimoto H, Akiguchi I, Onodera M, Huang CL. Blood-brain barrier is impaired in the hippocampus of young adult spontaneously hypertensive rats. Acta Neuropathol. 2004;107:532-8.
3. Olsen TS, Bruhn P, Oberg RG. Cortical hypoperfusion as a possible cause of 'subcortical aphasia'. Brain. 1986;109(3):393-410.

4. He J, Zhang Y, Xu T, Zhao Q, Wang D, Chen CS. Effects of immediate blood pressure reduction on death and major disability in patients with acute ischemic stroke: the CATIS randomized clinical trial. JAMA. 2014;311:479-89. 
5. Jauch EC, Saver JL, Adams HP, Bruno AJr, Connors JJ, Demaerschalk BM. Guidelines for the early management of patients with acute ischemic stroke: a guideline for healthcare professionals from the American Heart Association/American Stroke Association. Stroke. 2013;44:870-947.

6. Ishitsuka K, Kamouchi M, Hata J, Fukuda K, Matsuo R, Kuroda J. High blood pressure after acute ischemic stroke is associated with poor clinical outcomes: Fukuoka Stroke Registry. Hypertension. 2014;63:54-60.

7. Leonardi-Bee J, Bath PM, Phillips SJ, Sandercock PA. IST Collaborative Group. Blood pressure and clinical outcomes in the International Stroke Trial. Stroke. 2002;33:1315-20.

8. Arima H, Chalmers J, Woodward M, Anderson C, Rodgers A, Davis S. Lower target blood pressures are safe and effective for the prevention of recurrent stroke: the PROGRESS trial. J Hypertens. 2006;24:1201-8.

9. Ntaios G, Lambrou D, Michel P. Blood pressure change and outcome in acute ischemic stroke: the impact of baseline values, previous hypertensive disease and previous antihypertensive treatment. J Hypertens. 2011;29:1583-9.
10. Mazya M, Egido JA, Ford GA, Lees KR, Mikulik R, Toni D. Predicting the risk of symptomatic intracerebral hemorrhage in ischemic stroke treated with intravenous alteplase: safe Implementation of Treatments in Stroke (SITS) symptomatic intracerebral hemorrhage risk score. Stroke. 2012;43:1524-31.

11. Qureshi AI, Ezzeddine MA, Nasar A, Suri MF, Kirmani JF, Hussein HM. Prevalence of elevated blood pressure in 563,704 adult patients with stroke presenting to the ED in the United States. Am J Emerg Med. 2007;25:32-38.

12. Jusufovic M, Sandset EC, Bath PM, Karlson BW, Berge E. Scandinavian Candesartan Acute Stroke Trial Study Group. Effects of blood pressure lowering in patients with acute ischemic stroke and carotid artery stenosis. Int J Stroke. 2015;10:354-9.

13. Lee JM, Zhai G, Liu Q, Gonzales ER, Yin K, Yan P. Vascular permeability precedes spontaneous intracerebral hemorrhage in stroke-prone spontaneously hypertensive rats. Stroke. 2007;38:3289-91.

Стаття надійшла до редакції 23.10.2017

\title{
Н.О. Перцева, Д.I. Чуб \\ ГЛІКОЗИЛЬОВАНИЙ ГЕМОГЛОБІН ЯК ФАКТОР ПРОГНОЗУ ПРОГРЕСУВАННЯ ДІАБЕТИЧНОЇ НЕФРОПАТІЇ У ХВОРИХ НА ЦУКРОВИЙ ДІАБЕТ 1 ТИПУ
}

\author{
Д3 «Дніпропетровська медична академія МОЗ України» \\ кафедра ендокринології \\ (зав. - д. мед. н., дои. Н.О. Периева) \\ вул. Пастера, 26, Дніпро, 49000, Україна \\ $S E$ «Dnipropetrovsk medical academy of Health Ministry of Ukraine» \\ Department of Endocrinology \\ Pastera str., 26, Dnipro, 49000, Ukraine \\ e-mail: borisovadi@ukr.net
}

Ключові слова: иукровий діабет, діабетична нефропатія, ивидкість клубочкової фільтрації, ліпідограма, альбумінурія

Key words: diabetes mellitus, diabetic nephropathy, glomerular filtration rate, lipidogram, albuminuria

Реферат. Гликозилированный гемоглобин как фактор прогноза прогрессирования диабетической нефропатии у больных сахарным диабетом 1 типа. Перцева Н.О., Чуб Д.И. Целью работы было предложить математическую модель прогноза развития диабетической нефропатии у больных СД1 на основе определения уровня гликозилированного гемоглобина - как фактора развития и прогрессирования 